\title{
Susceptibility of Cultivated Plants to Sumatran Elephant (Elephas maximus sumatranus) in The Human Elephants Conflict Area in Aceh Province
}

\author{
Kaniwa Berliani ${ }^{1,2 *}$, Hadi Sukadi Alikodra ${ }^{3}$, Burhanuddin Masy'ud ${ }^{3}$, Mirza Dikari Kusrini ${ }^{3}$
}

\author{
${ }^{1}$ Graduate School of Bogor Agricultural University, Dramaga Main Road, Campus IPB Dramaga, Bogor, Indonesia 16680 \\ ${ }^{2}$ Biology Department, Faculty of Mathematics and Natural Science, Sumatera Utara University \\ ${ }^{3}$ Department of Forest Resource Conservation and Ecotourism, Faculty of Forestry, Bogor Agricultural University, Academic \\ Ring Road, Campus IPB Dramaga, PO Box 168, Bogor, Indonesia 16680
}

Received December 28, 2015/Accepted March 30, 2016

\begin{abstract}
Study on human-elephant conflict was conducted in Aceh Province in August 2013-April 2014 to assess susceptibility of farms by crop raiding elephants. The locations were determined by selected areas impacted by elephant conflict including Cot Girek, Mane, Meureudu, Sampoiniet, and Pantai Ceureumen. 150 respondents was interviewed to assess the variety of the commodity plant species cultivated by local community within study areas, species of damaged commodity plants, species of undamaged commodity plants, and the planting system. There were 29 species considered as commodity plants cultivated by farmers. Moreover, 5 commodity plants were considered as high risk plants damaged by elephant including areca, banana, oil palm, paddy, and rubber. On the other hand, species considered as low risk or undamaged consist of cacao, coffee, chili, candlenut, and patchioli. Those low risk or undemaged commodity plants species have a potential to be promoted as elephant-friendly crop commodities in area adjacent to elephant habitat based on the analysis and the categorization of susceptibility of cultivated plants against crop raiding elephant. One of the problems of human-elephant conflict is crop raiding of village farms. It is assumed that elephants might destroy a particular species therefore information on the species could assist farmers in selecting appropriate crop to be planted. There is a risk that current polyculture and monoculture planting system used by farmers will not prevent farms from crop raiding elephants.
\end{abstract}

Keywords: commodity plant, sumatran elephant, human-elephant conflict, crop damage

*Correspondenceauthor,email:kaniwa.berliani@yahoo.com,ph.: +62-81361775560

\section{Introduction}

Conflict between human and elephant has occurred in various areas close to the elephant's habitat (Sitaati et al. 2003; Zhang \& Wang 2003; Gubbi et al. 2014). In Indonesia, various authors have observed the conflict between human and elephant in Sumatera. The distribution of sumatran elephant (Elephas maximus sumatranus) currently is in southern part of Lampung (South Sumatera) Province, southern part of Bengkulu, southern part of Jambi, Riau, North Sumatera, and Aceh Province. According to the National Elephant Conservation Strategy and Action Plan for 2007-2017, currently, the number of sumatran elephants in those areas are between 2400-2800. The number of Sumatran elephants has decreased by $35 \%$ from $2800-4800$ in 1980s which were distributed in 44 locations in Sumatera (Soehartono et al. 2007). The elephant population has been threatened due to lost of habitats, poaching and direct conflict with human (Santiapillai \& Jackson 1990; Leimgruber et al. 2003; Nyhus \& Tilson 2004; Hedges et al. 2005; Soehartono et al. 2008). Various studies in Sumatera have reported that conflict between human and elephants has increased since 1982 (Haris 1988). As the consequence, of the decrease of sumatran elephant population and its habitats in the last 30 years, sumatran elephants have been catagorized as critically endangered (CR) based on the Red List of IUCN (IUCN 2011) and Appendix I of CITES (WCMC 2011).

Conflicts between human and elephants are mostly caused by crop raiding in community cultivation areas around elephant's habitat. Fragmentation of elephant's habitat has been increasing thus the availability of elephant's natural fodder source has declined significantly. Habitat degradation and expantion of human activities has rised the conflict exposure between human and elephant and therefore the disturbance to local community plantation (Rood \& Singh 2008). Elephants have the ability to move in forested mountain slope then travel across secondary forests which is adjacent to farms or plantation areas (Cheeran \& Poole 1996; Nyhus et al. 2000; Nyhus \& Tilson 2004; Linkie et al. 2007). 
In order to optimize food searching, elephants enter plantations and crop raiding community's plantation at worst it can also damage houses (Sukumar 1990; Nyhus et al. 2000; Nyhus and Tilson 2004; Linkie et al. 2007).

The encounters between human and elephants often cause injuries and fatalities on both sides. Nyhus et al. (2000) stated that human-elephant conflict in Way Kambas have caused significant economical loss and drove the community to guard their farmland. Human-elephant conflict has been increasing in each year. Rood et al. (2008) have reported that there were 62 cases of conflict between human and elephants in Aceh Province in 1985-1997 and then increased to 316 cases in 2000-2007. However, it was reported 143 cases of human elephant conflicts all over Aceh between 2008 and 2014.

Wild elephants eat more than 400 different plant species. Elephants are known for its selectiveness of feed but elephants also eat several plant taxa which greatly different depending on areas, weather, and ecosystem (Fowler \& Susan 2006). Elephants is a browser (shrub eater), folivore (leaf eater), frugivore (fruit eater), seed eater, and eater of several others plant part such as bark, young stem, and roots, and elephants also have high feeding rate to fulfill mineral and energy requirements according to its body size, age, and sex (Poole 1996). Previous studies reported that elephants tend to choose a particular food commodity (Nyhus et al. 2000; Azmi et al. 2012; Sitompul 2004; Yogasara et al. 2012). Data on plant species consumed by sumatran elephant has been provided especially from the study of Abdullah et al. (2010) in protected forest area in the Aceh Besar District, Aceh Province. The most preferred plants are cempedak (Artocarpus sp.), tampu (Macaranga sp.), areca (Areca sp.), forest banana (Musa acuminata), rotan gelang (Calamus caesius), semantuk bulan (Artocarpus sp.), and rotan umbut
(Calamuscaesius); while non-preferred plants are paku pucuk (Dieranopteris pubigera) and mangkanang (Macaranga mangayi). Moreover, from other studies are also known that elephants feed paddy plant, corn, peanut, and cassava (Nyhus et al. 2000, in Way Kambas), palm trees (Sitompul 2004, in Bengkulu), and rubber trees (Yogasara et al. 2012, in Bengkalis). According to Azmi et al. (2012) in Aceh, other than those plant commodities, areca and sugarcane are also consumed by elephants. However, cacao, pepper, candlenut, chili, coffee nutmeg, patchioli, and citrus fruit are plants which are less damaged by elephants.

Furthermore, the study results showed that one cannot conclude whether elephants choose a particular food plant based on the fact that those plants are the dominant species planted by local community or that elephant has particular preferred commodity even though this commodity is not the dominant plant. Knowledge on this aspect is important to develop a strategy to mitigate and adapt the human-elephant conflict situation by promoting less preferred commodities by elephants yet have economical potentials. The aims of this study were (1) to identify species of commodity plant which has potential to be promoted in human-elephant conflict areas by analyzing the relationship between the commodities cultivated by local community and the elephant crop raiding, (2) to analysis and categorize the susceptibility of cultivated plants against elephant crop raiding, and (3) to formulate the alternative crop arrangements in order to reduce the risk of crop damage by elephants.

\section{Methods}

Schedule and study area The study was carried out in August 2013-April 2014. Surveys of human-elephant conflict in various areas in Aceh Province was started in December 2012 to May 2013. The study was conducted in 5

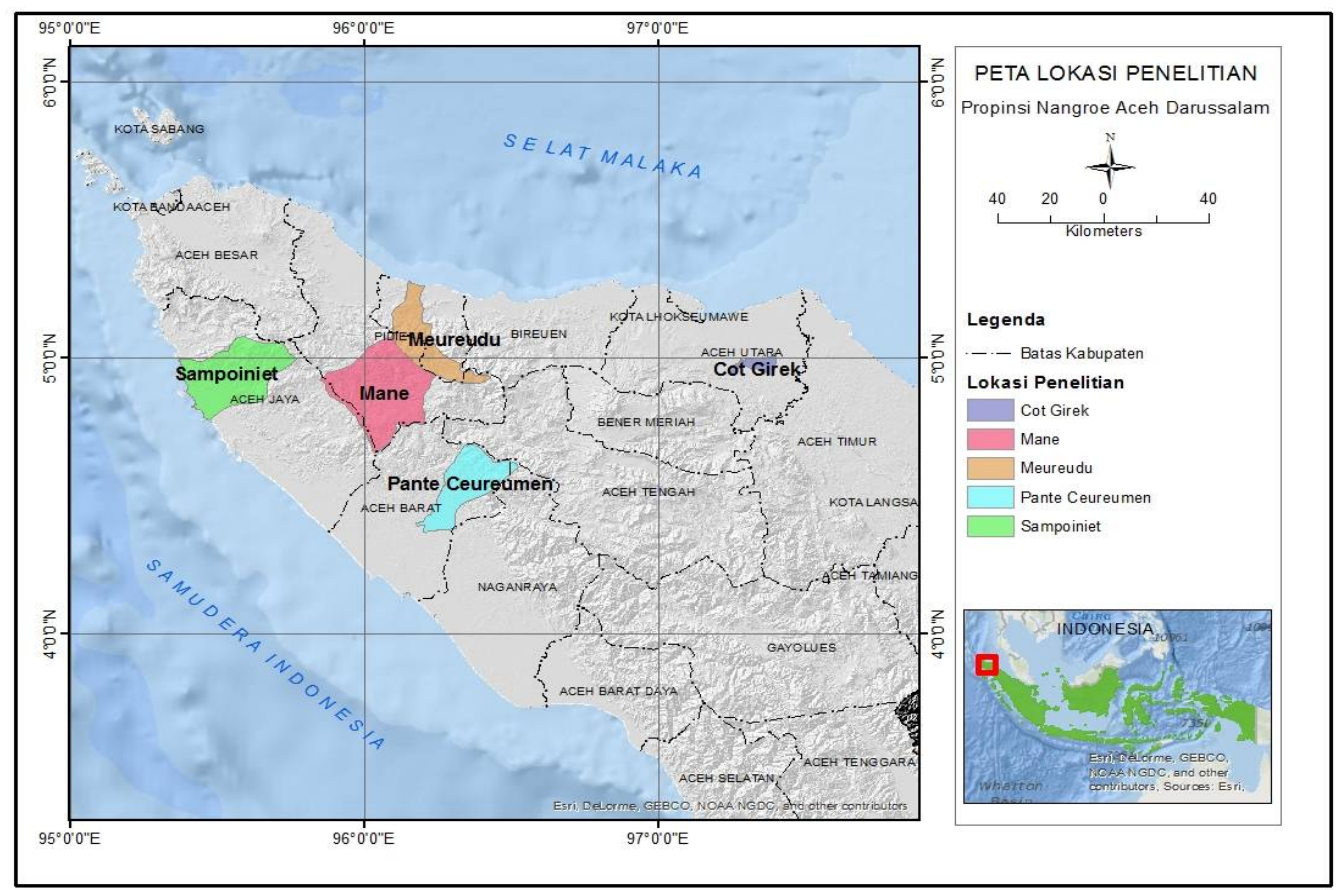

Figure 1 Map of study location. 
districts in Aceh Province including Cot Girek, Mane, Meureudu, Sampoiniet, and Pante Ceureumen Districts (Figure 1). The selection of study areas was based on the frequency of human-elephant conflict reported by local community and public media.

Data collection Information on the most commodities planted by local community and the most raided plants by elephants were obtained by interview and questionaire results from local community. Respondents for this study were chosen from 5 districts that represent human-elephant conflict areas. The interviews were carried out by using purposive sampling method to the plantation owners that experience direct impact of elephant's disturbance. We also interviewed customary leader and sub districts government officers. Total respondents for each district were 30 persons (Nazir 2003). Therefore, the total respondent in 5 districts were 150 persons. Generally, respondents were asked about the variation of commodity plants owned by the respondents, commodity plant that damaged by elephant, commodity plants that were not damaged by elephant, and planting system of the commodity plants.

Data analysis The identification method of commodity plants species which were damaged by elephant was referred to van Steenis (2005) in order to obtain scientific name and local name of a commodity plant. The data obtained during the field observation were analyzed descriptively and calculated based on Kendal Tau correlation (Quadratullah 2014) to determine the relationship between cultivated commodity plants and the one damaged by elephants. Moreover, we also determined the relationship between cultivated commodity plant and the one was not damaged by elephants. Determination of cultured plant species susceptibility was based on the degree of the damage caused by elephants according to community judgment. There are 4 susceptibility categories used for classifying cultured plant susceptibility; high (damage percentages $>15 \%$ ), moderate (damage percentage 5-14\%), low (damage percentage $<5 \%$ ), and no damage (damage percentage $=0 \%$ ).

Table 1 Seasonal plant species planted by Aceh communities in human-elephant conflict areas

\begin{tabular}{lll}
\hline Local names & Species & Family \\
\hline Cucumber & Cucumis sativus & Cucurbitaceae \\
Cassava & Manihot esculenta & Euphorbiaceae \\
Peanut & Arachis hipogea & Fabacea \\
Soya & Glicyne max & Fabacea \\
Patchioli & Pogostemon cablin & Lamiaceae \\
Banana & Musa sp. & Musaceae \\
Paddy & Oryza sativa & Poaceae \\
Sugar cane & Sacharum officinarum & Poaceae \\
Corn & Zea mays & Poaceae \\
Chili & Capsicum frutescens & Solanaceae \\
\hline
\end{tabular}

Table 2 Annual plant species planted by Aceh communities in human-elephant conflict area

\begin{tabular}{|c|c|c|}
\hline Local names & Species & Family \\
\hline Mango & Mangifera indica & Anocordiaceae \\
\hline Areca & Areca саtechu & Arecaceae \\
\hline Coconut & Cocos nucifera & Arecaceae \\
\hline Oil palm & Elais gueenensis & Arecaceae \\
\hline Sago & Metroxylon sago & Arecaceae \\
\hline Candlenut & Aleurites moluccana & Euphorbiaceae \\
\hline Albizzia & Albizia chinensi & Fabacea \\
\hline Teak & Tectona grandis & Lamiaceae \\
\hline Durian & Durio zibethinus & Malvaceae \\
\hline Langsat & Lansium domesticum & Meliaceae \\
\hline Mahogany & Swietenia mahagoni & Meliaceae \\
\hline Cacao & Theobroma cocoa & Meliaceae \\
\hline Nutmeg & Myristica fragrans & Myristicaceae \\
\hline Jabon & Neolamarckia cadamba & Rubiaceae \\
\hline Coffee & Coffea arabica & Rubiaceae \\
\hline Citrus lemon & Citrus aurantifolia & Rutaceae \\
\hline Rambutan & Nephelium lappaceum & Sapindaceae \\
\hline
\end{tabular}




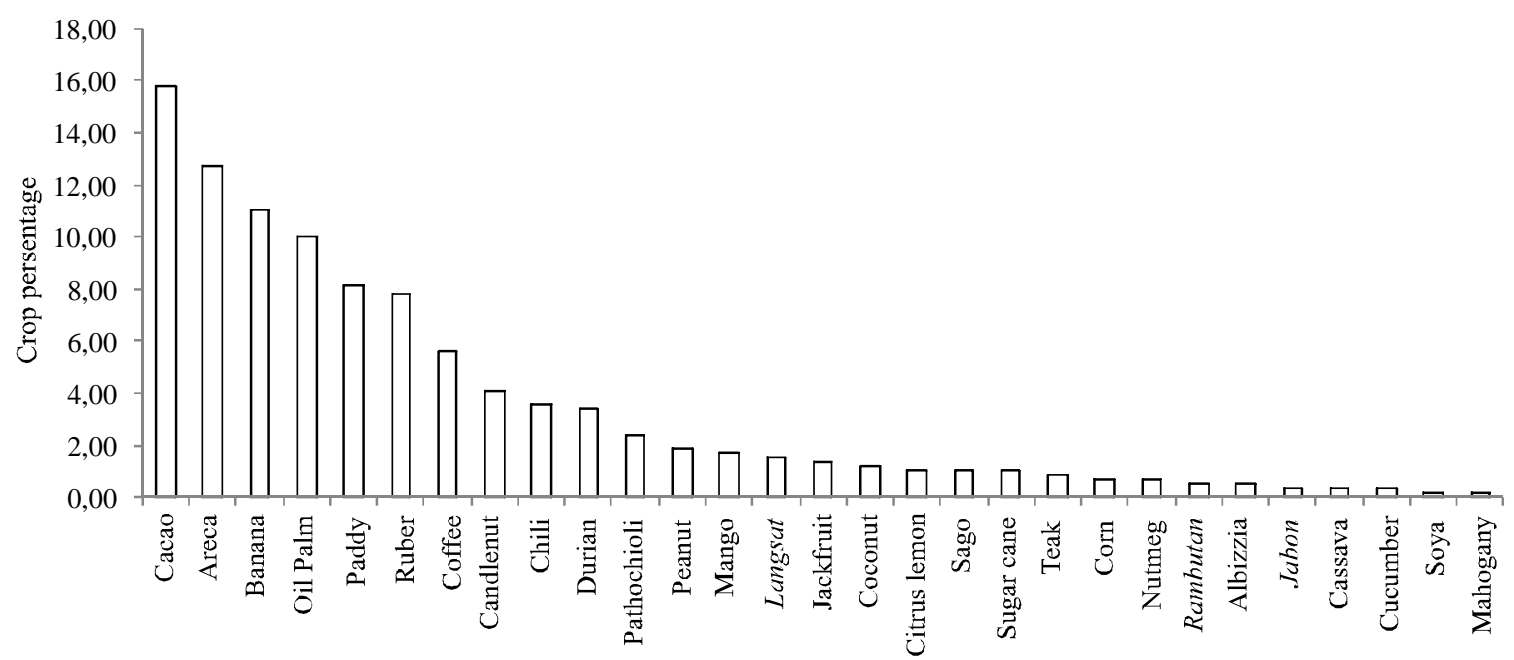

Figure 2 Cultivated plants of local community in 5 sub-district of Aceh Province.

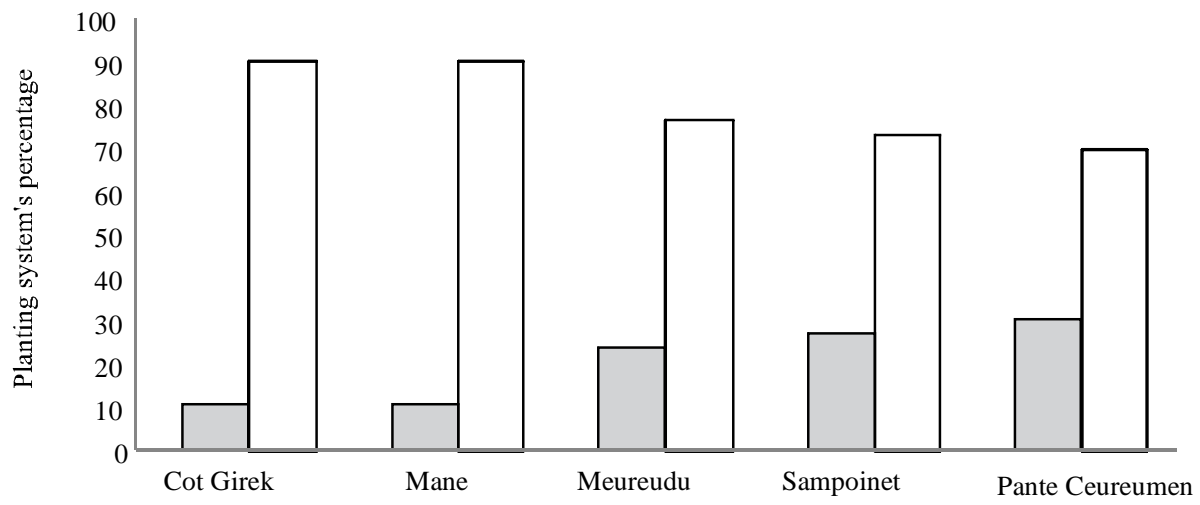

Figure 3 Planting system of local community's commodity plants in conflict area. Monoculture (ㅍ), Policulture ( $\square$ ).

\section{Results and Discussion}

Commodity species plant and planting system Based on the interview result, there were 29 commodity plants cultivated by local community in human-elephant conflict areas which consisted of 10 species from 7 families on seasonal plant (Table 1), and 19 species from 12 families are perrenial plant (Table 2). Regarding the plant species, local community mostly planted Arecaceae, Euphorbiaceae, Fabaceae, Meliaceae, and Poaceae families. The most and the least plant cultivated by local community in human-elephant conflict area based on the interview could be seen at Figure 2 . The most cultivated plant was cacao (Theobroma cocoa, Meliaceae) which was $15.29 \%$ from total commodities. The least cultivated plant was mahogany (Swietenia mahagoni, Meliaceae) which was only $0.17 \%$ from total commodity cultivated in the survey area.

According to $15.29 \%$ of respondents, cacao ( $T$. cacao, Meliaceae) was the most cultivated plant in human-elephant conflict area. Cacao has high economical value which could reach IDR21.050,00 per kg (DISBUN 2015) and the demand of cacao for domestic consumption and export has increased. Mangoensoekarjo (2007) stated that there are an increasing trend to use cacao for various food and other products. Consequently this plant was cultivated in major scale for commercial purpose. Moreover, climate and weather factors in that area were suitable for cacao thus cacao was mostly cultivated by local community in the study area. On the other hand, $0.16 \%$ respondents have answered that nutmeg (Myristica fragrans, Myristicaceae) was the least cultivated by local community in the study area. We found only in Sampoinet Sub-District that cacao cultivated as commodity plant.

In human-elephant conflict areas, farmers tend to follow polyculture than monoculture planting system. According to the respondent anwers, polyculture system used by $90 \%$ respondents in Cot Girek and Mane, $76.67 \%$ respondents in Meureudu district,73.33\% respondents in Sampoinet, and $70 \%$ respondents in Pante Ceureumen. Compared to other areas Pante Ceureumen has the highest percentage (30\%) that use monoculture planting system which can be seen in Figure 3.

Commodity plants species damaged and undamaged by elephant Out of 29 commodity plants species cultivated by 


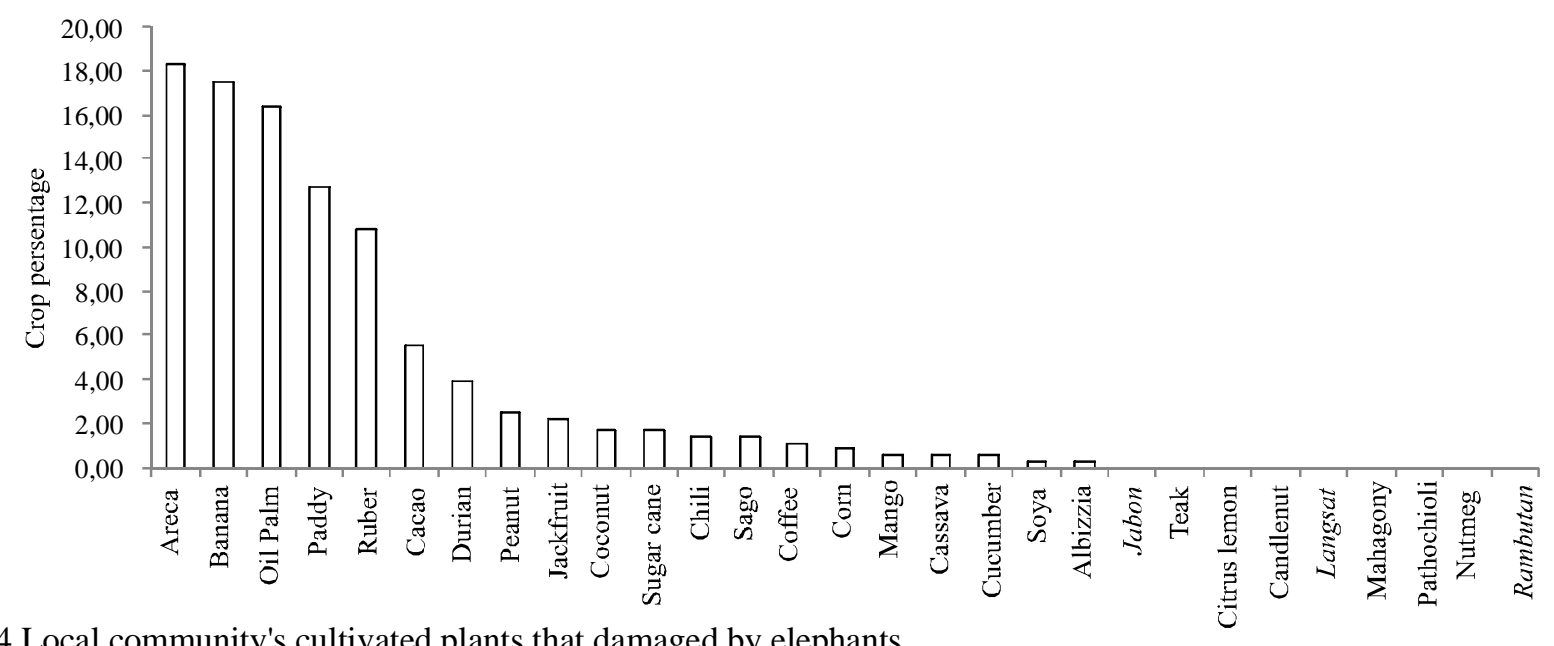

Figure 4 Local community's cultivated plants that damaged by elephants.

local community, there were 20 plants species that were impacted by elephant crop raiding. Then, 5 plants that were mostly damaged by elephant based on the answers of respondents were areca (A. catechu, Arecaceae) with $18.28 \%$ respondents, banana (Musa sp., Musaceae) with $17.45 \%$ respondents, oil palm tree (Elais gueenensis, Arecaceae) with $16.34 \%$ respondents, paddy plant (Oryza sativa, Poaceae) with $12.74 \%$ respondents, and rubber tree (Havea brassiliensis, Euphorbiaceae) with $10.80 \%$ respondents. On the other hands, albizzia (Albizia chinensis, Fabacea) with $0.28 \%$ respondents was the least damaged plants by elephants. The further detail could be seen in Figure 4.

Elephants destroy commodity plant by eating all plant part or particular plant part, trampling or breaking plant thus that plant experience disturbance on its natural growth, and finally the plants are dead. From the study result, it is known that cacao ( $T$. cocoa, Meliaceace) was stated by respondents as the least damaged plant by elephants. Even though there were damages found on cacao but it was due to elephant's mobility rather than elephant consumption. Cacao plantation was one of the main commodity plants in the study area which traversed by elephants when the elephants roamed within its home range. It was similar to the study of Monney et al. (2010) which stated that elephants in Ghana do not consume cacao for its feed, but sometimes elephants just pluck the cacao.

Commodity plants which was fed by elephants indicate that there is palatability factor. According to Fowler and Mikota (2006), elephants could be very selective to choose their food and will choose some plant taxa from different plants depending on area, weather, and ecosystem. According to Stokke and du Troit (2000), elephants choose quality and quantity of fodder species which is related to fiber content, palatability of plant species so that the food are easily digested by elephants. Thus it was speculated that if there is commodity plants which are not consumed by elephant, it may be related to the food content and physicalchemical composition of the plants which are not palatable for elephants so that elephants tend to avoid those plants.

From the study result, there were 2 plant species from
Arecaceae family (according to respondent answers) are the most impacted plant by elephants which are areca (chosen by $18.28 \%$ respondents) and palm trees (16.34). The result of our study is in agreement to study results of Azmi et al. (2012) and Sitompul (2004). Elephants destroy vegetation of Arecaceae family by 2 ways. In seedling phase, all plant parts are damaged and eaten by elephants. In tree phase, the most damaged plant parts by elephants were leaf, plants shoot (top part of stem with soft structure), and leaves stalk. Selection of young plants was not limited only to Arecaceae family but also other families. In Bengkalis, elephants also like rubber tree $(H$. brassiliensis) and feed all parts of rubber plant seedling and also feed young rubber stem (Poniran 1974; Yogasara et al. 2012). After rubber tree in tree phase, elephants will eat young branches with a little leaves and bark by pealing the bark using their trunk and their front feet (Poniran 1974). That explains that seedling phase was the critical phase to be damaged by elephants.

There were some of commodity plants species which the whole part of plants were eaten by elephants thus their damage potential is high. According to the survey, $17.45 \%$ respodents informed that elephans raid banana in study research area. Moreover, $12.74 \%$ respondents said that paddy from Poaceae family also among the most damaged plants. It was inline with the study result of Nyhus et al. (2000) in Way Kambas area where the elephant was fond of the paddy plants.

Elephants eat all parts of rice plant from seedling phase up to mature phase. Elephants are generally fond of young leaf or tree tip because the young leaf may have high nutritional content and it is easier to be digested compared with bark and root. For the same reason elephant eat plants from Arecaceae family due to its high hard fiber and water content. Elephants were also fond of rice plant from Poaceae family due to its high content of carbohydrate.

There were 23 plant species in human-elephant conflict areas which were not damaged by elephants. Then, 5 plant species that were not eaten by elephant according to the answers are (Coffea arabica, Rubiaceae) with $12.78 \%$ respondents, candlenut (Aleurites moluscana, Euphorbiaceae) with $10.57 \%$ respondents, chili (Capsicum 


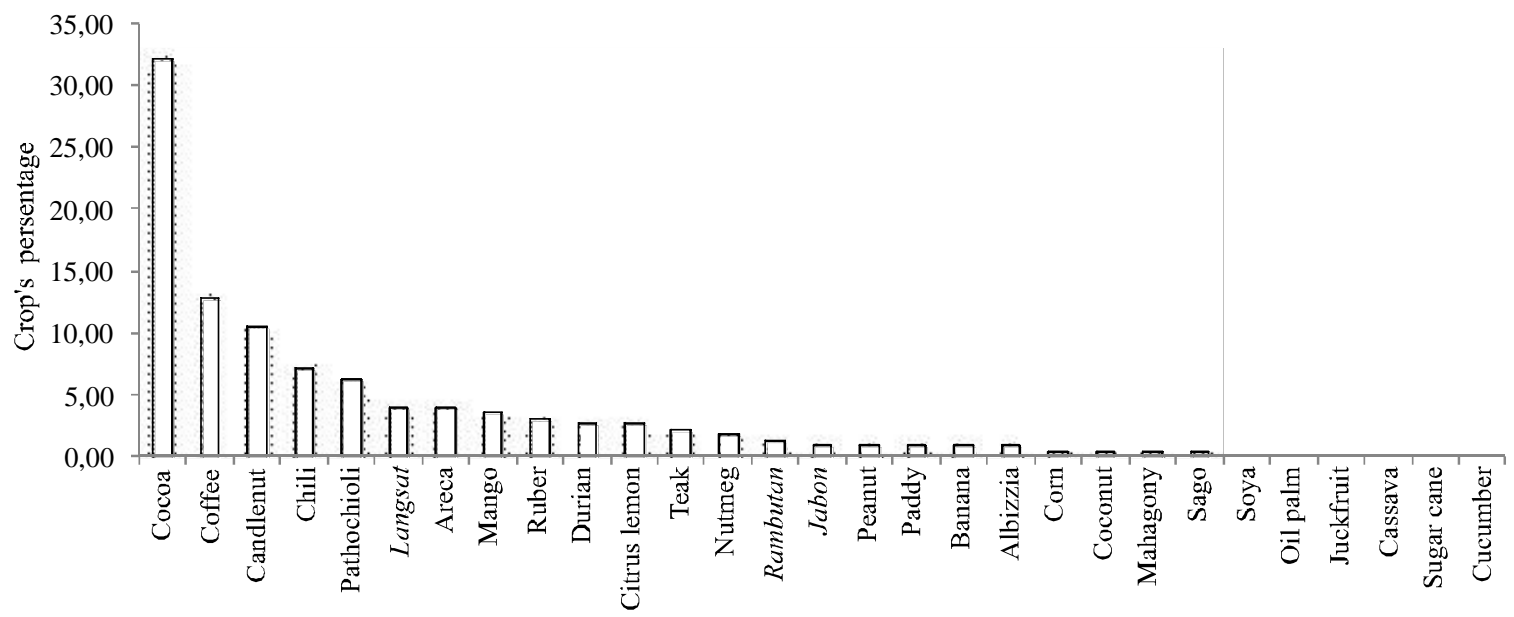

Figure 5 Local community's cultivated plants that were not damaged by elephants.

frutescens, Solanaceae) with $7.05 \%$ respondents, and patchioli (Pogostemon cablin, Fabaceae) with 6.17\% respondents. Then, sago palm (Metroxylon sago, Arecaceae) was the least raided plant by elepant in human-elephant conflict area $(0.44 \%$ respondents $)$. It was due to sago palm is less cultivated by local community thus this member of Arecaceae family was least damaged by elephants. The detail information is provided in Figure 5.

Elephants did not consume plants from Meliaceae family which is probably caused by the taste of the plants which were not good enough for elephants. According to $12.78 \%$ respondents, coffee (C. arabica, Rubiaceae) were not damaged by elephants because they do not eat the coffee plan. However, we found break of stem or branches of coffee plant due to traverse route of elephants. According to Azmi et al. (2012), patchioli and chili were not significantly impacted by elephants in Aceh. Ekanayaka et al. (2011) stated that chili in southern Sri Lanka was damaged due to elephant trample, not due to feeding. There were $7.05 \%$ respondents said that chili ( $C$. frustescen) was not damaged by elephants. It was probably because chili was not palatable for elephants and it caused burnt sensation on their trunk and mouth. According to Hedges and Gunaryadi (2009), when elephants eat chili unintentionally, they will show an unpleasant behaviour. Thus, it may be caused by their prior experience so that elephants do not eat chili. According to $10.57 \%$ respondents, candlenut (Aleurites moluccana) also was not damaged by elephants. It was saved from the damage probably due to its chemical compound which could not be digested by elephants. According to Harini et al. (2000), the seed of candlenut contains volatile essential oil which has laxative characteristic thus it could not be digested directly by elephants. Elephants seem to avoid candlenut plants even though the plants were cultivated by local community in large scale. Moreover, $6.17 \%$ respondents said that patchioli (Pogostemon cablin, Lamiaceae) was not damaged, was not consumed, and even was not trampled by elephants. It was probably due to the aroma of patchioli's oil has caused elephants to avoid this plant. According to Kardinan (2005), patchioli has high content of volatile oil thus it produces strong unique aroma. Volatile oil content in leaf (5-6\%) is higher than in stem or branch or stalk $(0.4-0.5 \%)$.
Commodity plants cultivated by local community were significantly related to elephant crop raiding in each district which were Cot Girek district has $\tau=0.630$ and $\mathrm{p}=0.000$, Mane district with $\tau=0.660$ and $\mathrm{p}=0.000)$, Meureudu district with $\tau=0.629$ and $p=0.000$, Sampoiniet district with $\tau=0.826$ and $p=0.000$, and Pantai Ceureumen district with $\tau$ $=0.773$ and $p=0.000$. The same information could also be seen from the data of 5 human-elephant conflict areas. Commodity plant species cultivated by local community has significant relationship with commodity plant species damaged by elephants in Aceh Province $(\tau=0.542, p=$ 0.000 ). The data shows that almost all cultivated commodity plants were damaged by elephants with different level of damages.

In fact there is consistency in respondents answer about the most raided plant species by elephants with undamaged plant species. The top 5 of commodities damaged by elephants were areca, banana, oil palm tree, paddy plant, and rubber plant (Figure 3). From the list we can see that banana, palm tree and paddy plant is not included in the undamaged list (Figure 4). However, areca and rubber tree were included into list of non-raided species with small percentage. It shows that areca and rubber trees sometimes could be saved from elephant raid in particular locations.

In 5 human-elephant conflict areas in Aceh Province, plants species cultivated by local community was closely related to plant damaged by elephants. There was a close relationship between plants cultivated by local community and plant damaged by elephants. This damage was probably due to plant cultivated by local community was palatable for elephants thus elephants will mostly raid and eat that plants. Eventually, risk of elephant raid to local community cultivated plant will keep increasing. Otherwise, if local community cultivates plant which was not palatable for elephants, the risk of elephant raid will be reduced. This raid case should be considered carefully in order to reduce the probability because elephants will learn from their experiences to find food in farmland areas. This finding was in accordance with Monney et al. (2010) which stated that elephants have ability to develop adaptation to eat various plant species.

Plant commodities cultivated by local community were 
significantly related to plant species which were not damaged by elephant in the following locations, Cot Girek District $(\tau=$ $0.521 ; p=0.001)$, Mane District $(\tau=0.547 ; p=0.000)$, Meureudu District ( $\tau=0.764 ; p=0.000)$, Sampoiniet District $(\tau=0.549 ; p=0.001)$, and Pantai Ceureumen District $(\tau=$ $0.598 ; p=0.000)$. The same thing could also be applied in 5 human-elephant conflict areas in Aceh Province. The cultivated commodity species was significantly related to commodity plant species which was not damaged by elephants $(\tau=0.444 ; p=0.001)$. It means that all cultivated commodity plants have potentials to be saved from elephant raid if farmers choose no elephant raid risk to be cultivated.

Plants cultivated by local community in 5 study locations showed different relationship toward undamaged plants. In Cot Girek District, Mane District, Mereudu District, Sampoiniet District, and Pante Ceureumen District, plants cultivated by local community have relationship to plants which were not damaged by elephants. It was probably because the local community in those locations also cultivates plants which were nöt palatable for elephants thus those plants were not raided by elephants. Local community tend to use polyculture planting system than monoculture planting system for plant cultivation. It was caused by the expectation of each farmer for various agricultural products from their farmlands. Both, monoculture and polyculture planting systems applied by farmers in conflict areas have risk of elephant raid. It was due to the plants cultivated in the farmland were plants which preferred by elephants thus elephants will be attracted to visit the farmland. According to Sukumar (2003), plant damage due to elephants was also speculated to be caused by the high preferrences level of elephants to plants cultivated by farmers. This circumstance could intensify conflict between farmers and elephants. Thus, monoculture and polyculture planting systems applied by farmers in human-elephant conflict areas still contained risk of elephant raid. It was assumed that polyculture planting system which combine commodity plants with high and low risk of elephant raid could increase damage risks to commodity plants which has low risk of elephant raid. To reduce the risk of elephant raid to farmland, selection of alternative commodity plant to be cultivated in farmland was required. Farmers need to cultivate alternative plant which was not preferred by elephants but still has economical value. From this study, $15.82 \%$ respondents said that the most cultivated commodity by society was cacao ( $T$. cacao, Meliaceae) from all cultivated commodities. Moreover, $32.16 \%$ respondents said that cacao was commodity plants which mostly safe from elephant raid. Thus, this plant together with coffe ( $C$. arabica, Rubiaceae), chili $(C$. frutescens, Solanaceae), candlenut (A. moluccana, Euphorbiaceae), and patchioli ( $P$. cablin, Lamiaceae) were several alternative commodities which could be cultivated with monoculture planting system. These plants could become local community superior commodities in humanelephant conflict areas. Therefore, it was expected to become one of effective and efficient long-term solutions to address elephant conservation problem and local community economical problem which address human-elephant conflict proportionally.

Commodity plant susceptibility toward elephant crop raiding Based on community experience, plant species damaged by elephants were 20 species as depicted in Figure 4. There is a common phenomenon that describes the difference in cultured plant susceptibility level of elephant disturbance. Consistent answers were given by almost all respondents in 5 sub-districts about plant species which damaged and not damaged by elephant. Those answers

Table 3 Plant species susceptibility level toward elephant's disturbance in human-elephant conflict area of Aceh Province

\begin{tabular}{|c|c|c|c|c|c|}
\hline \multirow{2}{*}{ Local names } & \multirow{2}{*}{ Species } & \multirow{2}{*}{ Damaged by elephant (\%) } & \multicolumn{3}{|c|}{ Categories of susceptibility } \\
\hline & & & High & Moderate & Low \\
\hline Areca & Areca catechu & 18,82 & $\sqrt{ }$ & & \\
\hline Banana & Musa sp. & 17.45 & $\sqrt{ }$ & & \\
\hline Oil palm & Elais gueenensis & 16.34 & $\sqrt{ }$ & & \\
\hline Paddy & Oryza sativa & 12.74 & & $\sqrt{ }$ & \\
\hline Rubber & Havea brassiliensis & 10.80 & & $\sqrt{ }$ & \\
\hline Durian & Durio zibethinus & 3.88 & & & $\sqrt{ }$ \\
\hline Peanut & Arachis hipogea & 2.49 & & & $\sqrt{ }$ \\
\hline Jackfruit & Arthocarpus heterophyllus & 2.22 & & & $\sqrt{ }$ \\
\hline Coconut & Cocos nucifera & 1.66 & & & $\sqrt{ }$ \\
\hline Sugar cane & Sacharum officinarum & 1.66 & & & $\sqrt{ }$ \\
\hline Chili & Capsicum frutescens & 1.39 & & & $\sqrt{ }$ \\
\hline Coffee & Coffea arabica & 1.11 & & & $\sqrt{ }$ \\
\hline Corn & Zea mays & 0.83 & & & $\sqrt{ }$ \\
\hline Mango & Mangifera indica & 0.55 & & & $\sqrt{ }$ \\
\hline Cassava & Manihot esculenta & 0.55 & & & $\sqrt{ }$ \\
\hline Cucumber & Cucumis sativus & 0.55 & & & $\sqrt{ }$ \\
\hline Soya & Glicyne max & 0.28 & & & $\sqrt{ }$ \\
\hline Albizzia & Albizia chinensi & 0.28 & & & $\sqrt{ }$ \\
\hline
\end{tabular}




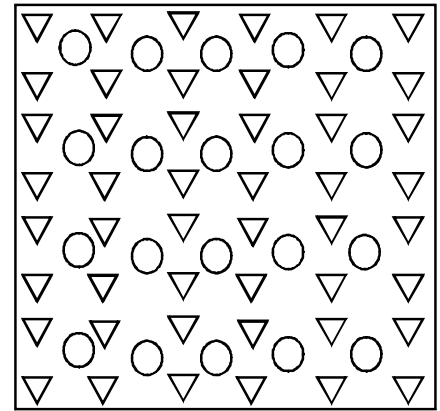

A

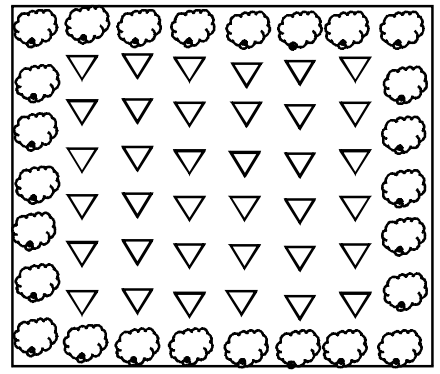

$\mathrm{C}$

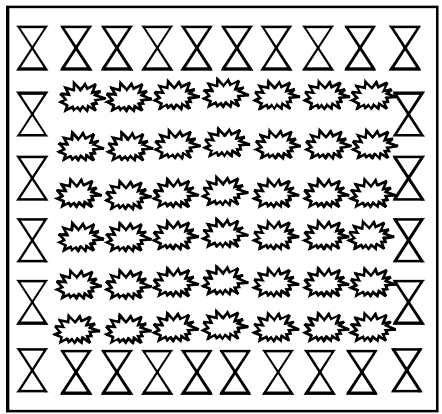

B

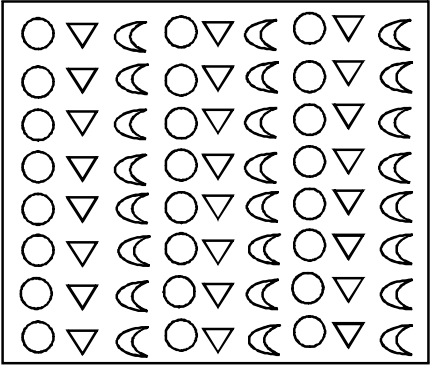

D

Figure 6 Model of arrangement pattern for cultured plant's planting. Cacao $(\nabla)$, coffe $(\bigcirc)$, teak $(又)$, citrus lemon ( $\left.\xi_{m}^{m}\right)$, Chili $(\varangle)$, candlenut $\left(\tilde{w}^{3}\right)$.

support the conclusion about the differences of susceptibility of particular cultivated plant species toward elephant disturbance. Figure 4 shows high percentage respondents that give judgment on cultivated plants which damaged by elephants. From Figure 4 we could determine the category of cultivated plant susceptibility toward elephant disturbance as presented in Table 3.

Alternative arrangement of commodity plant to reduce risk of elephant crop raiding Based on the susceptibility of damaged plants we could use the information in order to reduce the human elephant conflict that affects to the economical loss. From this information, farmers could apply appropriate monocultural and polycultural planting system. If the desired planting system is monoculture planting system, the selected plants should be from plant species which is either not damaged by elephant or has low to moderate susceptibility level. As alternative, based on the result of the study, plant species which could be planted using monoculture planting system in conflict area which are also functioned as superior commodity plants include cacao, coffee, chili, candlenut, and nilam. Those plants could also be planted in polyculture system with arrangement according to their susceptibility levels.

Plant species which are not damaged by elephant, not preferred, or plant with low susceptibility level could be planted as buffers or barriers to reduce risk of elephant disturbance. On the other hand, plants with high susceptibility level and preferred by elephant for feed such as areca, banana, rice plant, and palm should be planted further from elephant traverse area. Several models of plant arrangement pattern in conflict areas which are expected to reduce elephant disturbance risk are shown in Figure 6.

\section{Conclusion}

The most cultivated plants by local community in humanelephant conflict areas were cacao while the least cultivated was nutmeg. The most damaged plants due to the elephant disturbances were areca, banana, oil palm, paddy plant, and rubber trees. Moreover, the plants which were not damaged by elephants were cacao, coffee, candlenut, chili, and patchioli. Based on the damage observation, there are at least 4 plant species with high susceptibility level $(15 \%)$ such as areca, banana, oil palm, and paddy. There were and three species (paddy, rubber, cacao tree) with moderate susceptibility level $(5-14 \%)$ and 14 species with low susceptibility level $(<5 \%)$. Therefore, the selection of commodity plants which were not preferred by elephants is a potential strategy to adapt in human-elephant conflict situation because those plants have low palatability for elephants. Commodity plants such as cacao, coffee, chili, candlenut, and patchioli were several alternative commodities which could be developed in areas adjoined to elephant habitats.

\section{Recommendation}

To reduce elephant disturbance risk, monoculture system could be developed by using commodity plant species which is either undamaged by elephants or has low susceptibility level as superior commodity such as cacao, coffee, candlenut, chili and patchioli. Meanwhile, polyculture planting system could be developed by combining plant arrangement which is undamaged by elephant with low to moderate susceptibility level.

Moreover, polyculture planting system which combines commodities with high risk and low risk of elephant raid 
could increase the risk of disturbance of commodity with low risk of elephant raid. Therefore polyculture planting system could be applied by combining several commodity plants with low risk of conflict with wild elephants, thus it could support human-elephant coexistence concept.

\section{References}

Abdullah, Djufri, Asiah MD. 2010. Analisis Kesesuaian Habitat dan Pemetaan Kawasan Perlindungan Gajah (Elephant Sanctuary) di Hutan Terganggu sebagai Upaya Menyelesaikan Konflik Gajah dengan Manusia. Banda Aceh: Unsyiah.

Azmi W, Hasballah, Trysani F, Kholis M, Kiswayadi D, Linkie M. 2012. Conservation Response Unit in Aceh. Annual Proggres Report. Banda Aceh: FFI.

Cheeran JV, Poole TB. 1996. The exploitation of Asian elephants. In: Taylor VJ, Dunstone $\mathrm{N}$, editors. The Exploitation of Mammal Populations. London: Chapman \& Hall.

[DISBUN] Dinas Perkebunan Provinsi Aceh. 2015. Informasi Pasar Komoditi Perkebunan Provinsi Aceh. Banda Aceh: Dinas Perkebunan Propinsi Aceh.

Ekanayaka KK, Arceiz AC, Rupasinghe M, Postorini J, Fernando P. 2011. Pattern of crop raiding by asian elephants in a human dominated landscape in Southeastern Sri Lanka. Gajah 34: 20-25.

Fowler ME, Mikota SK. 2006. Biology, Medicine and Surgery of Elephants. Iowa: Blackwell Publishing Professional.

Gubbi S, Swaminath MH, Poornesha HC, Bhat R, Raghunath R. 2014. An elephantine challenge: human-elephant conflict distribution in the largest asian elephant population Southern India. Journal Biodiversity and conservation 23(3):633-647. http://dx.doi.org/10.1007/ s10531-014-0621-x.

Harini EKS, Zuhud EAM, Sangat EAM, Damayanti, EK. 2000. Kamus Penyakit dan Tumbuhan Obat Indonesia (Etnofitomedika I). Jakarta: Yayasan Obor Indonesia.

Haris Z. 1988. Operasi Ganesa. Bandung: Alumni.

Hedges S, Tyson MJ, Sitompul AF, Kinnaird MF, Gunaryadi DA. 2005. Distribution, status, and conservation needs of asian elephants (Elephas maximus) in Lampung Province, Sumatra, Indonesia. Biological Conservation 124:35-48. http://dx.doi.org/101016/j.biocon.2005.01. 004.

Hedges S, Gunaryadi D. 2009. Reducing human-elephant conflict: Do chillie help dater elephant from entering crop fields.Oryx journal 44(1):139-146.

[IUCN] International Union for Conservation of Nature. 2011. World Conservation Union-Red List of Threatened Species. Wold wide web http://www.iucnredlist.org/ document [22 April 2013].

Kardinan A. 2005. Tanaman Penghasil Minyak Atsiri Komoditi Wangi Penuh potensi. Jakarta: PT Agro Media Pustaka.

Leimgruber P, Gagnon JB, Wemmer C, Kelly DS, Songer MA, Selig ER. 2003. Fragmentation of asia's remaining wildlands: implications for asian elephant conservation. Animal Conservation 6:347-359. http://dx.doi.org/ $10.1017 / \mathrm{S} 1367943003003421$.

Linkie M, Dinata Y, Nofrianto A, Williams LN. 2007 Patterns and perceptions of wildlife crop raiding in and around Kerinci Seblat National Park, Sumatra. Animal Conservation 10:127-135. http://dx.doi.org/10.1111/ j.1469-1795.2006.00083.x.

Mangoensoekarjo, S. 2007. Manajemen tanah dan pemupukan budidaya perkebunan. Gadjah Mada University Press. Jogyakarta.

Monney KA, Dakwa KB, Wiafe ED. 2010. Assessment of crop raiding situation by elephants (Loxodonta africana cyclotis) in farm around Kakum conservation area, Ghana. International Journal of Biodiversity and Conservation 2(9):243-249.

Nazir M. 2003. Metode Penelitian. Jakarta: Ghalia Indonesia.

Nyhus PJ, Sumianto, Tilson R. 2000. Crop raiding elephant and conservation implication at Way Kambas National Park, Sumatera Indonesia. Oryx Journal 34(4):262-274. http://dx.doi.org/10.1017/S0030605300031331.

Nyhus PJ, Tilson R. 2004. Agroforestry, elephants, and tigers: balancing conservation theory and practice in human-dominated landscapes of Southeast Asia. Agriculture Ecosystems \& Environment 104:87-97. http://dx.doi.org/10.1016/j.agee.2004.01.009.

Quadratullah MF. 2014. Statistik Terapan, Teori, Contoh Kasus dan Aplikasi dengan SPSS. Yogyakarta: Andi.

Poniran. 1974. Elephant in Atjeh, Sumatera. Cambridge Journal 12: 576-580.

Poole JH. 1996. Coming of Age with Elephants. New York: Hyperion Press; London: Hodder\& Stoughton.

Rood J, Singh R. 2008. Asian elephant (Elephas maximus) in the Rajaji National Park. The Journal of American Science 4:34-48.

Santiapillai C, Jackson P. 1990. The Asian Elephant: An action plan for its conservation. Gland Switzerland: IUCN/SSCAsian Elephant Specialist Group. IUCN.

Sitaati NM, Walpole MJ, Smith RJ, Williams NL. 2003. Predictive spatial aspects of human-elephant conflict. Journal of Applied Ecology 40(4):667-677. http://dx. doi.org/10.1046/j.1365-2664.2003.00828.x. 
Sitompul AF. 2004. Conservation implication of humanelephant interaction in two nasional park in Sumatera [thesis]. Athens: University of Georgia.

Soehartono T, Susilo HD, Sitompul AF, Gunaryadi D, Purastuti EM, Azmi W, Fadhli N, Stremme C. 2007. The Strategic and Action Plan for Sumatran and Kalimantan Elephant. Jakarta: Ministry of Forestry.

Stokke S, du Toit JK. 2000. Sex and size related differences in the dry season feeding patterns of elephant in Chobe. National Park. Bostwana. Ecography 23:70-80.

Sukumar R. 1990. Ecology of the asian elephant in southern India. 2. Feeding-habits and crop raiding patterns. Journal of Tropical Ecology 6(01):33.

Sukumar R. 2003. The Living Elephants: Evolutionary Ecology, Behavior and Conservation. New York: Oxford
University Press.

van Steenis CGGJ. 2005. Flora. Jakarta: Pradnya Paramita.

[WCMC] World Conservation Monitoring Centre. 2011. IUCN Red List of threatened species version 2011.1 http//www.iucnredlist.org [17 Februari 2013].

Yogasara FA, Zulkarnaini, Saam Z. 2012. Analisis faktorfaktor yang mempengaruhi intensitas konflik antara gajah dengan manusia di Kecamatan Mandau dan Kecamatan Pinggir Kabupaten Bengkalis. Jurnal Ilmu Lingkungan 6(1):63-81.

Zang L, Wang N. 2003. An initial study on habitat conservation of asian elephant (Elephas maximus), with a focus on human elephant conflict in Simao China. Biological Conservation 112:453-459. http://dx.doi.org/ 10.1016/S0006-3207(02)00335-X 